\title{
A non-native bryozoan creates novel substrate on the mudflats in San Francisco Bay
}

\author{
Chela J. Zabin ${ }^{1,2, *}$, Rena Obernolte ${ }^{2}$, Joshua A. Mackie ${ }^{3}$, Jackson Gentry ${ }^{4}$, \\ Leslie Harris ${ }^{5}$, Jonathan Geller ${ }^{6}$ \\ ${ }^{1}$ Smithsonian Environmental Research Center, 3152 Paradise Drive, Tiburon, California 94965, USA \\ ${ }^{2}$ Department of Environmental Science and Policy, University of California, Davis, 2142 Wickson Hall, One Shields Avenue, \\ Davis, California 95616, USA \\ ${ }^{3}$ Biological Sciences, San Jose State University, San Jose, California 95192, USA \\ ${ }^{4}$ Marine Science Institute, 500 Discovery Parkway, Redwood City, California 94063, USA \\ ${ }^{5}$ Natural History Museum of Los Angeles County, 900 Exposition Boulevard, Los Angeles, California 90007, USA \\ ${ }^{6}$ Moss Landing Marine Laboratories, Moss Landing, California 95039, USA
}

\begin{abstract}
A non-native bryozoan, Schizoporella errata, forms extensive patches of free-living balls and reef-like structures (bryoliths) on the mudflats in south San Francisco Bay, California. The ball-like bryoliths range from 2 to $20 \mathrm{~cm}$ in diameter, and the reef-like structures can be nearly $1 \mathrm{~m}$ across. While $S$. errata is known to form bryoliths in other locations, free-living aggregations like these have not been reported. Colony morphology appears to be a plastic trait as analysis of relationships among forms using cytochrome oxidase subunit I (COI) nucleotide sequence data revealed no genetic separation. We recorded $>50$ species of algae and invertebrates living on and in the bryoliths and determined the invasion status for 34 of the 50 species. Of the 34, $25(74 \%)$ were non-natives and included fouling species that require hard substrate. The bryoliths may thus facilitate colonization by invaders on the mudflats and serve as stepping stones between the limited hard substrate habitats in the Bay.
\end{abstract}

KEY WORDS: Bryoliths · Bryozoans · Schizoporella · Habitat modification · Invasive species · Facilitation

Resale or republication not permitted without written consent of the publishe

\section{INTRODUCTION}

Predicting how invasive species will behave in their new ranges is one of the goals of invasion biology. Many marine invasive species are members of the fouling community - organisms like sponges, tunicates, barnacles and bryozoans that attach to maritime structures, e.g. boat hulls. It is reasonable to expect such organisms to be limited by hard substrate. However, some species that are usually hard-substrate dependent and sessile have non-attached forms that can thrive on soft-bottom substrates and are potentially mobile. These include species of crustose coralline algae that also form rhodoliths (e.g. Bosence 1983, Foster 2001); hermatypic corals that form coralliths (e.g.
Glynn 1974); and species of normally attached encrusting or branching bryozoans that can form bryoliths (e.g. Rider \& Enrico 1979, Cuffey \& Sorrentino 1985, Kidwell \& Gyllenhaal 1998, James et al. 2006).

For a normally sessile invasive species, the ability to take on a free-living form confers several potential advantages: (1) use of a wider range of habitat types, (2) dispersal of adult organisms/colonies, and (3) increased reproductive potential via fragments. For example, the Atlantic sponge Hymeniacidon sinapium forms small colonies that are attached to hard substrate in the rocky intertidal zone of Central California (J. Pearse unpubl. data), but is also able to invade mudflats by taking on a large, free-living ball shape (Wasson et al. 2001). Gracilaria salicornia, a non-native alga 
in the Hawaiian Islands, grows attached to the reef but also forms unattached 'tumbleweeds' on sand flats that may aid dispersal through viable fragments (C. J. Zabin pers. obs.).

Non-native marine species that create 3-dimensional structures in soft-bottom habitats can also have significant ecological impacts, facilitating the presence of obligate hard-substrate organisms, creating living space for other organisms, and in some cases altering the quality of the nearby benthos (e.g. Posey 1988, Ricciardi et al. 1997, Crooks \& Khim 1999, Bruno et al. 2005, Rodriguez 2006). In a literature review, Bruno et al. (2005) found that non-native species facilitated the presence of native species at least as often as that of other non-native species. However, it might be reasoned that when a non-native species creates a novel substrate type, other non-natives may be more likely than natives to either (1) be pre-adapted to use the new substrate or (2) display the environmental plasticity to do so. For example, Heiman et al. (2008) found that reefs created by the Australian tubeworm Ficopomatus enigmaticus in a predominantly soft-bottom estuary in Central California supported abundant communities of non-native amphipods and polychaetes. Native species associated with native oysters also inhabited the worm reefs, but non-native species were much more abundant in the tubeworm reefs than on oysters, suggesting differential facilitation of non-native species by this new foundation species (Heiman et al. 2008).

In 2006, we became aware of another organism typically thought of as hard-substrate dependent, living as an unattached form on the mudflats in San Francisco Bay, California. Spheroidal colonies of a bryozoan, ranging from golf ball to football size ( 2 to $20 \mathrm{~cm})$, were found in large numbers in the shallow subtidal zone in the southern part of the bay (henceforth South Bay). Additional sampling revealed 2 other forms: a robust foliaceous form consisting of open multi-laminar tubes, and a tubular structure formed from an anastomosing mass of closed tubes. All of these forms are found on muddy bottoms and appear to be unattached to hard substrate.

Bryoliths are well-known from the fossil record. However, only a few bryozoan species today form massive structures; unattached ball-like bryoliths are unusual and have not been reported from the West Coast of the United States (Osburn 1912, Banta 1972, Bradstock \& Gordon 1983, Scholz \& Hillmer 1995, Hillmer et al. 1996, James et al. 2006).

The bryolith-forming species fit morphological descriptions for Schizoporella errata (Waters 1878) and resemble specimens of $S$. errata described by Tompsett et al. (2009) as well as a putative specimen of $S$. errata collected by J.A.M. from Australia. Several Schizoporella species, including $S$. errata, are reported to have massive growth forms (Cocito et al. 2000, Ferdeghini et al. 2000, Morgado \& Tanaka 2001), but freeliving spherical forms have not been reported.

Several non-native Schizoporella species, including $S$. errata, are known from San Francisco Bay in their more usual encrusting forms (Carlton 1979, Cohen \& Carlton 1995, J. Inabe unpubl.). The taxonomy of the Schizoporella serialis/errata/pungens complex requires revision (Winston 2004). While we cannot resolve these taxonomic issues here, we were interested in determining whether the bryolith-forming species was a previously unreported species or an unreported morphotype.

It has been suggested that while estuaries are more invaded than rocky shores, the majority of invasive marine species are hard-substrate dwellers (Wasson et al. 2005). Species such as Ficopomatus enigmaticus and the bryolith-forming Schizoporella, which create new hard substrate in invaded estuaries, might thus be predicted to differentially promote non-native species. However, high numbers of non-native species have also been reported from soft-bottom habitats in San Francisco Bay (Cohen \& Carlton 1995, Lorenzi et al. 2007). Unlike the addition of seawalls, pier pilings or other topographically simple anthropogenic structures, the softer biogenic substrate provided by the bryoliths was also likely to facilitate the presence of species that bore, burrow and make use of mud-filled crevice spaces.

With this in mind, we predicted that the bryoliths in San Francisco Bay would harbor high numbers of obligate hard-substrate organisms which otherwise would not be present on the mudflats, and that bryolith-associated organisms would be a mixture of softbottom and hard-substrate dwellers. It was not clear whether non-native species would be differentially promoted by the presence of this novel substrate.

In the present study we (1) describe the distribution of the bryoliths in San Francisco Bay, (2) detail the morphology of the bryoliths, (3) clarify the identity of the bryolith-forming Schizoporella, and (4) enumerate the infauna and epifauna associated with this novel habitat to determine whether non-native species are disproportionately represented compared to other habitat types in the South Bay.

\section{MATERIALS AND METHODS}

Bryolith collection and distribution. The mudflats where the bryoliths are located are too soft to walk on during low tide when the bryoliths are exposed, but can be approached by boat in some places and traversed at mid-tide when the water supports some body weight. We made an initial collection in this manner in Novem- 
ber 2006. We were able to detect bryoliths by touch and collect them by hand and nets, but could not see them due to the extreme turbidity of the water $(<5 \mathrm{~cm}$ visibility). Over the course of the next 5 mo, we collected bryoliths using a rock dredge and/or an otter trawl deployed from 1 of 2 powerboats: the $90 \mathrm{ft}(27.4 \mathrm{~m})$ 'Brownlee' and the $25 \mathrm{ft}(7.6 \mathrm{~m})$ 'Lucille'. Tows on the 'Brownlee' were made opportunistically as part of a public education program at the Marine Science Institute (MSI, Redwood City). MSI makes 340 such trips $\mathrm{yr}^{-1}$ and carries out 3 to 4 bottom trawls trip ${ }^{-1}$, each running $\sim 10$ to $15 \mathrm{~min}$, using a $2.75 \times 5.5 \times 10 \mathrm{~m}$ trawl. While most of the MSI trips are made in the South Bay, the boat works in the Central Bay and Delta $7 \mathrm{wk} \mathrm{yr}^{-1}$. Bryoliths have only come up in the South Bay trawls.

We generally recorded only presence/absence data from the 'Brownlee' collections, although some specimens were collected for morphological work and others were preserved in $70 \%$ ethanol for genetic analysis. In addition, we made 7 tows over $3 \mathrm{~d}$ during high tides aboard the 'Lucille' to collect bryoliths for more detailed analyses (Fig. 1). We attempted to collect specimens from the northernmost and southernmost extents of the population (as determined from the extensive tows of the 'Brownlee') as well as from sites on the east and west sides of the bay. Specimens were deposited at the California Academy of Sciences (catalogue numbers: CAIZ182423-26).

Bryolith morphology. At 6 sites where the densely packed ball form dominated, we measured 3 axes of all bryoliths collected: (1) L: the longest dimension; (2) I: the intermediate dimension $90^{\circ}$ to the midline of the first axis, and (3) S: the shortest dimension $90^{\circ}$ to the midline of the second axis. For the smaller specimens, measurements were made to the nearest $1 \mathrm{~mm}$ using calipers; for the larger specimens, measurements were made with a transect tape, and were accurate to $5 \mathrm{~mm}$ (accuracy was determined by repeated measures). To determine how close to spherical the bryoliths were, we calculated the coefficient of variation (CV) for L, I, and S (based on James et al. 2006). In addition, we made observations on colony morphology and sectioned 10 bryoliths using a razor to visually examine colony formation.

Molecular comparison of morphotypes. We compared the partial cytochrome oxidase subunit I (COI) nucleotide sequences of 10 colonies. The samples encompassed the range of colony structural types: encrusting $(n=4)$, bulbous $(n=3)$, foliaceous $(n=2)$, and tubular $(\mathrm{n}=1)$. One encrusting colony tentatively identified as Schizoporella errata was collected by J.A.M. in 2000 from Manly, Sydney. Encrusting colonies were collected from intertidal rocks in San Francisco Bay at Coyote Point. Bryoliths were collected by towing from 6 sites as described above (Fig. 1). Specimens were preserved in $70 \%$ ethanol in the field. DNA was extracted from fragments of $\sim 20$ zooids colony ${ }^{-1}$ using DNeasy (Qiagen) mini centrifuge columns. Following previously described methods (Mackie et al. 2006), COI was amplified using universal primers LCO1490 and HCO2198. This product was reamplified using LCO1490 and a bryozoan-specific primer BH2161, and sequenced by BigDye chemistry from both ends using these primers. Sequences of 411589 base pairs were obtained and submitted to GenBank (accession numbers EU797458 to EU797467). A minimum spanning tree was constructed using TCS software (Clement et al. 2000).

Associated fauna. Nineteen bryoliths were collected from 4 sites for the analysis of associated epi- and infauna. Highly mobile fauna, such as fish and large crabs, were likely lost during dredging. To minimize further loss of mobile fauna, the bryoliths were placed

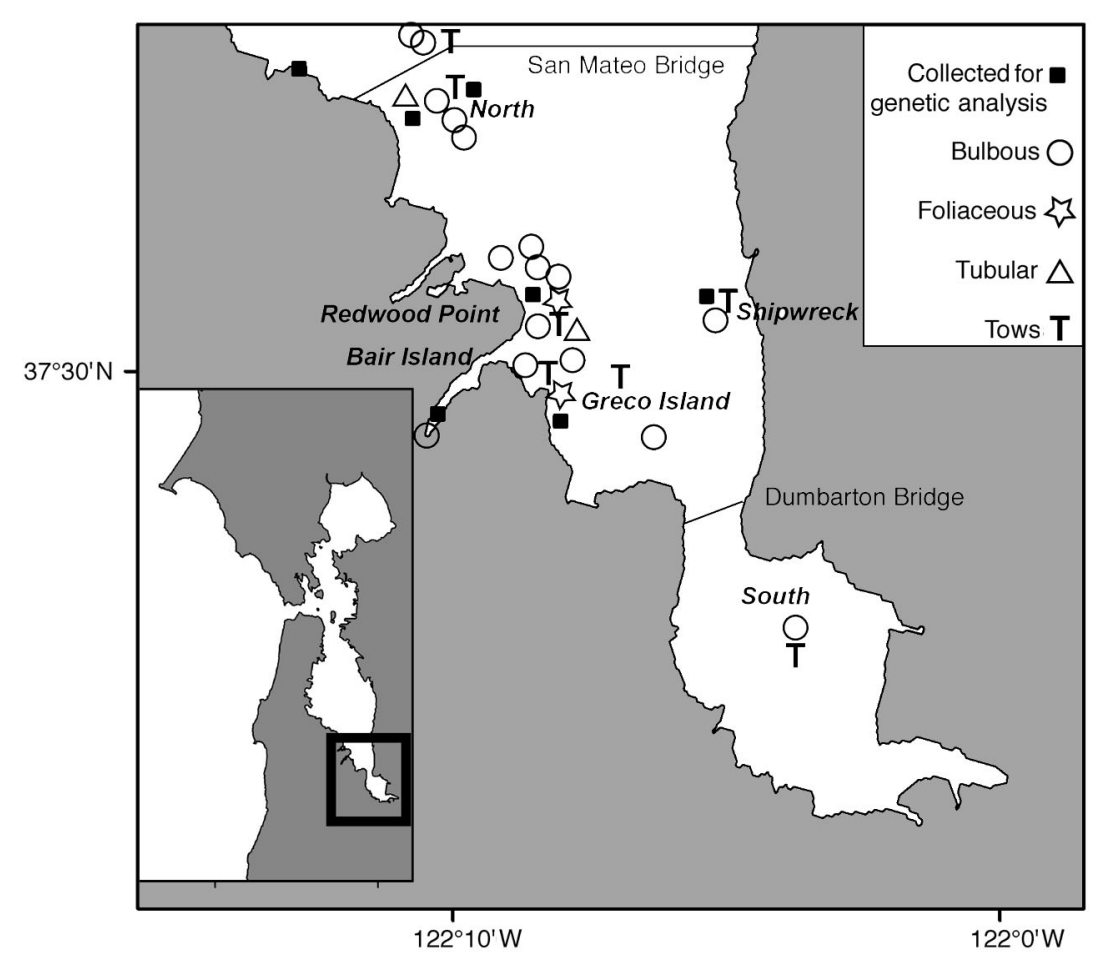

Fig. 1. San Francisco Bay, showing the sites where material was collected for genetic analysis, areas towed for studies of associated species and morphology, and the distribution of the different colony morphologies 
into nylon stockings or into separate tubs upon removal from the dredges. The bryoliths were either kept live in seawater tanks (up to $1 \mathrm{wk}$ ) until they could be worked on, or preserved in $70 \%$ ethanol after being fixed in formalin. The bryoliths were crushed and rinsed over a $1 \mathrm{~mm}$ sieve to remove organisms, which were then examined under a dissecting microscope. We counted and identified each morphotype to the lowest possible taxonomic level. Where we were able to identify organisms to species level, we used literature searches to determine biogeographic status (native, introduced, cryptogenic sensu Carlton 1996) and habitat type use (hard vs. soft substrate).

The relationships between bryolith volume and numbers of associated individuals and species (species richness) were explored using linear regression after data were transformed to meet assumptions of normality. Bryolith volume was calculated by using the abovementioned 3 axes to determine a mean radius for use in the formula for spherical volume. We considered volume as the independent variable; species richness and number of individuals were treated as dependent variables. We used multidimensional scaling plots (MDS, Primer v5.2.9 software, Primer-E) to informally examine differences between fauna associated with different colony morphologies and locations within the bay. For these plots, we used organisms for which we had species-level identifications, or those which represented the only individuals in a genus or family. The raw data were first standardized to account for differences in bryolith volume and then used to generate Bray-Curtis similarity measures to create the MDS plots. We noted other organisms that were found on other bryoliths during tows, but only included those that were associated with the 19 bryoliths collected for this portion of the study for the above analyses.
To determine whether non-native species were preferentially using bryoliths, we compared the percentages of non-native species associated with the bryoliths and those found on hard substrate and in benthic grabs during a rapid assessment survey of benthic organisms at the marinas closest to our study areas: Pete's Harbor and Coyote Point (Cohen et al. 2005). Pete's Harbor is within 2 to $3 \mathrm{~km}$ of one of our collection sites and Coyote Point is $\sim 10 \mathrm{~km}$ from a collection site. The marina survey (Cohen et al. 2005) was carried out by taxonomic experts who sampled for their specialist taxonomic groups across several types of substrata, including floating pontoons, wood, rocks, and mud benthos. As in our study, highly mobile fauna were likely underrepresented. While differences in methodology do not allow for direct comparison, we considered the list generated from the study by Cohen et al. (2005) to be a reasonably good sample of the species pool of organisms in the South Bay that could potentially live in or on the bryoliths.

\section{RESULTS}

\section{Bryolith distribution and abundance}

We found bryoliths from just north of the San Mateo bridge to just south of the Dumbarton bridge (Fig. 1), which is a north-south distribution of 10.8 nautical miles (n miles). We determined an east-west extent of $2.56 \mathrm{n}$ miles, excluding the specimens found inside Smith Slough in Redwood Creek (below Bair Island in Fig. 1). One bryolith was found at a depth of $3.5 \mathrm{~m}$ (at mean low low water, MLLW), but most were found at considerably shallower depths. Our methodology did not allow us to accurately mea-

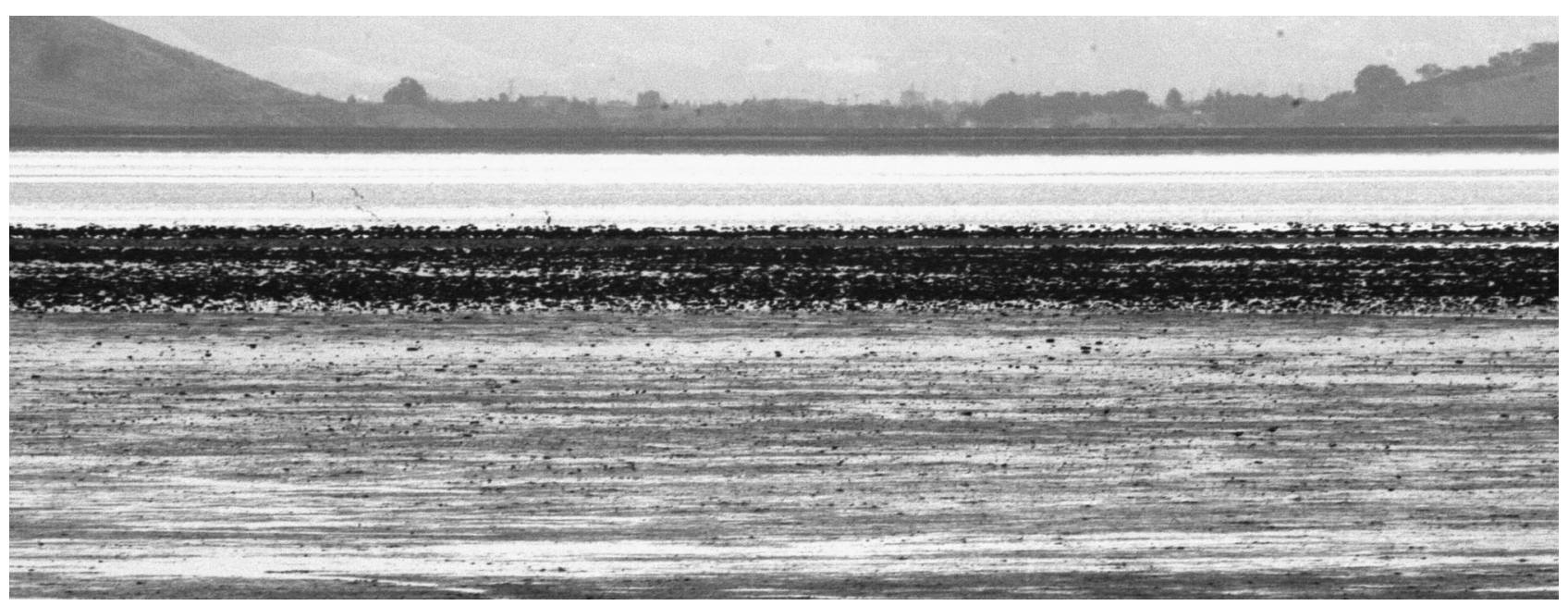

Fig. 2. Bryoliths exposed at low tide on Bair Island (Redwood City), seen here as a thick dark band 

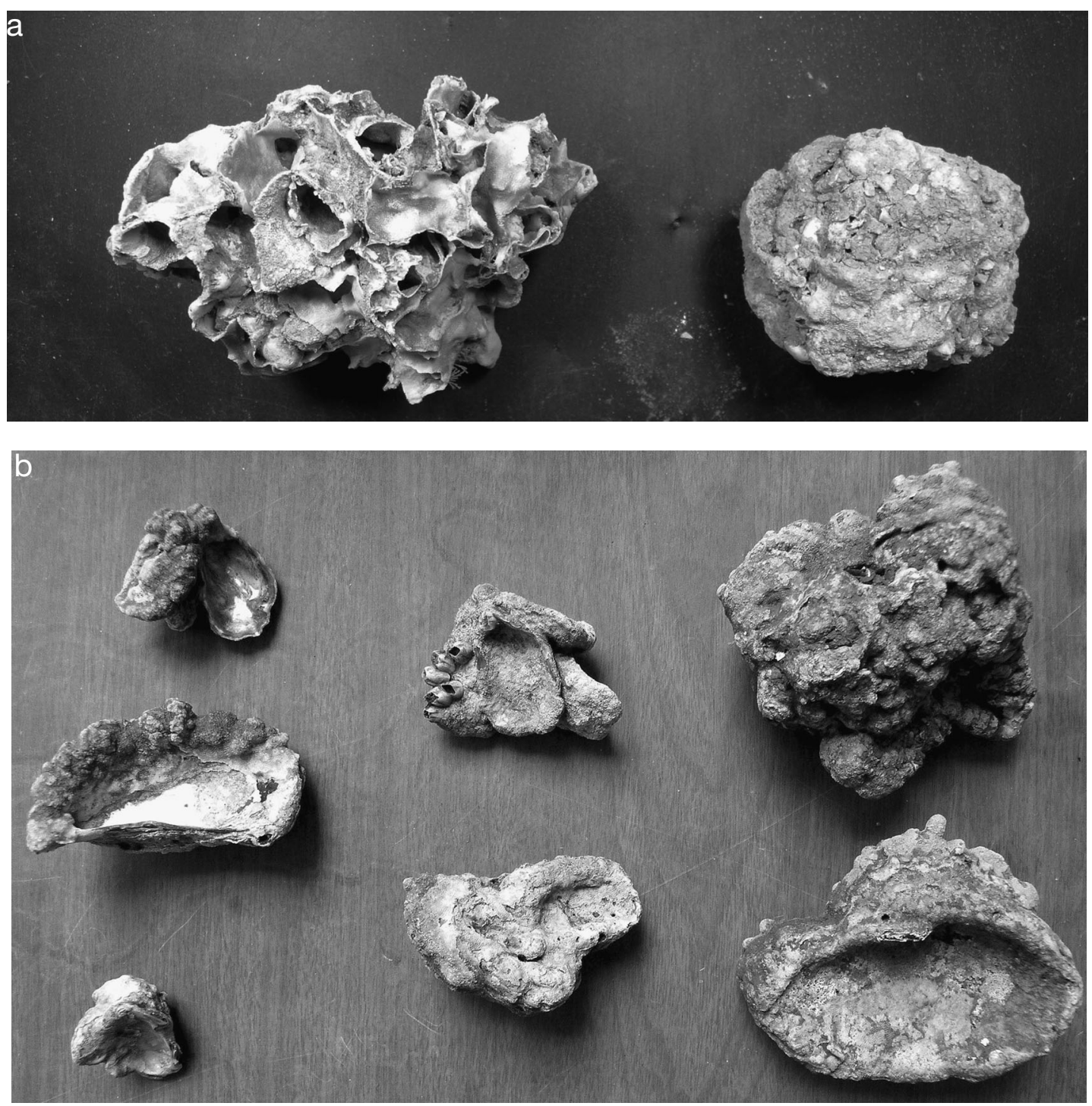

Fig. 3. (a) The 2 most common colony morphologies found in San Francisco Bay: left, foliaceous; right, bulbous. (b) Bryoliths in various stages of formation around bivalve shells

sure abundance (see 'Discussion'), but photographs taken from the 'Brownlee' at low tide (Fig. 2), in addition to the sonar surveys made on the 'Lucille', indicate a patchy distribution with areas of high abundance. Surveys using the boat sonar suggest that the Greco Island site $\left(37^{\circ} 31.972 \mathrm{~N}\right.$, $\left.122^{\circ} 11.098^{\circ} \mathrm{W}\right)$, where we found the greatest variety of morphotypes, has high densities of bryoliths. These could be seen continuously with the depth finder over a large triangular shaped area of $\sim 2.40 \mathrm{~km}^{2}$. There appear to be several smaller but dense patches throughout the western portion of the South Bay. One site east of Foster City ( $37^{\circ} 34.217 \mathrm{~N}$, $122^{\circ} 14.425 \mathrm{~W}$ ) was determined via boat surveys to be at least $40000 \mathrm{~m}^{2}$.

\section{Bryolith morphology}

We found 2 major types of colonies (Fig. 3a): those in which many layers of zooids are packed tightly over one another, creating a dense, solid structure ('bulbous'), and those which include empty, open tube-like shapes, created by 2 to 4 zooid layers ('foliaceous'). More rarely, we found a third form, which consisted of an anastomosing mass of closed tube-like shapes, with multiple zooid layers ('tubular'). While the bulbous colonies tended to also take on spheroidal or discoidal shapes and the foliaceous and tubular colonies tended to form massive, reef-like structures, these morphologies actually represent extremes of a continuum. Some bulbous colonies included foliaceous, open projections, 
Table 1. Bryolith mean dimensions $\pm \mathrm{SE}$ from 6 sites: $\mathrm{L}=$ longest axis; $\mathrm{I}=$ intermediate axis; $\mathrm{S}=$ smallest axis, in $\mathrm{cm}$ (see 'Materials and methods-Bryolith morphology' for definitions). $\mathrm{CV}=$ mean coefficient of variation $\pm \mathrm{SE}, \%$

\begin{tabular}{|lrrccc|}
\hline Site & $\mathrm{n}$ & $\mathrm{L}$ & $\mathrm{I}$ & $\mathrm{S}$ & $\mathrm{CV}$ \\
\hline South of San Mateo bridge & 6 & $18.8 \pm 2.1$ & $16.3 \pm 2.0$ & $11.2 \pm 0.5$ & $25 \pm 3$ \\
Shipwreck & 15 & $5.9 \pm 0.3$ & $3.8 \pm 0.3$ & $2.2 \pm 0.3$ & $41 \pm 3$ \\
Redwood Point & 7 & $15.4 \pm 3.2$ & $12.7 \pm 2.6$ & $9.2 \pm 1.8$ & $25 \pm 3$ \\
South of Dumbarton bridge & 14 & $7.0 \pm 0.6$ & $4.1 \pm 0.5$ & $2.7 \pm 0.44$ & $28 \pm 3$ \\
Bair Island & 10 & $10.9 \pm 1.1$ & $8.8 \pm 1.2$ & $7.0 \pm 0.6$ & $23 \pm 3$ \\
Greco Island & 15 & $8.6 \pm 0.7$ & $6.9 \pm 0.6$ & $5.3 \pm 0.4$ & $24 \pm 2$ \\
\hline
\end{tabular}

ranged from $5.9 \mathrm{~cm}$ at Shipwreck to $18.8 \mathrm{~cm}$ at the site South of San Mateo bridge. Based on their relatively low CVs (Table 1), the bryoliths at 4 sites were mostly spheroidal; at the site south of Dumbarton bridge, they tended to be spheroidal; and at Shipwreck, most of the bryoliths were discoidal. In general, smaller bryoliths tended to have retained the shape of their nuclei (usually a bivalve shell). and some of the tubular reef-like structures included sections of densely packed zooid layers. The bulbous colonies were clearly unattached, but the more delicate foliaceous and tubular forms always showed some sign of breakage, making it unclear whether some portion of the colony might have been attached to hard substrate, or to an even more massive bryozoan reef.

Dredge samples provided clues as to the formation of the bryoliths. Typical dredge hauls included clean bivalve shells, shells encrusted with a single bryozoan layer, shells with multiple layers, shells covered with thick layers but still retaining the overall shape of the underlying shell, and spherical bryoliths retaining little of the initial shape (Fig. 3b). We found shells in the center of many, but not all, of the bryoliths that we cut open. Mud, shell bits, worm tubes, barnacles, sponges and bivalves were also incorporated into a colony at various points in its formation. Bryoliths larger than golf ball size tended to have an identifiable 'dead' face, which was gray and devoid of bryozoan polypides. The presence of ovicells with visible larvae indicated that several of the bryoliths we collected were gravid.

Bryolith size and shape varied among the 6 sites (Table 1). The mean length of the longest dimension

\section{Molecular comparison of morphotypes}

COI sequence analysis revealed a lack of divergence among colony forms, suggesting that these are ecotypes. Analysis of 10 specimens distinguished 4 COI

Fig. 4. Parsimony network. Hatches in the network represent single nucleotide changes between adjoining haplotypes. Measures are based on a comparison of 544 nucleotides. Mean p-distance among the 10 colonies was $0.0064 \pm$ 0.0025 SE. The maximum (percentage) divergence between Haplotypes 1 and 4 was $1.03 \%$

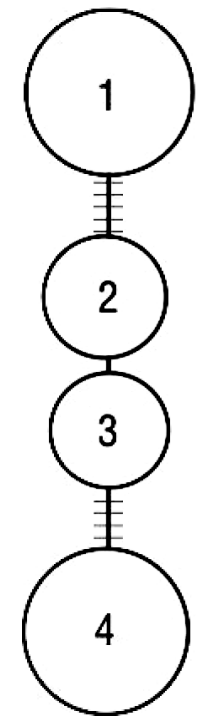

Table 2. Definition of cytochrome oxidase subunit I (COI) haplotypes of selected Schizoporella errata colonies from South Bay, San Francisco, and 1 colony from Australia

\begin{tabular}{|c|c|c|c|c|c|}
\hline $\begin{array}{l}\text { Colony } \\
\text { morphology }\end{array}$ & Haplotype & Site & Habitat & Coordinates & $\begin{array}{l}\text { GenBank } \\
\text { accession }\end{array}$ \\
\hline Bulbous & 1 & South of San Mateo bridge & Mudflat & $37.57608^{\circ} \mathrm{N}, 122.24994^{\circ} \mathrm{W}$ & EU797464 \\
\hline Bulbous & 1 & East shipwreck & Mudflat & $37.55869^{\circ} \mathrm{N}, 122.15492^{\circ} \mathrm{W}$ & EU797459 \\
\hline Encrusting & 1 & Coyote Point & Intertidal rocks & $37.59111^{\circ} \mathrm{N}, 122.31415^{\circ} \mathrm{W}$ & EU797462 \\
\hline Tubular & 1 & Little Coyote Point & $\begin{array}{l}\text { Overgrowing the sponge } \\
\text { Clathria prolifera }\end{array}$ & $37.34339^{\circ} \mathrm{N}, 122.14398^{\circ} \mathrm{W}$ & EU797466 \\
\hline Encrusting & 2 & Coyote Point & Intertidal rocks & $37.59111^{\circ} \mathrm{N}, 122.31415^{\circ} \mathrm{W}$ & EU797463; \\
\hline Foliaceous & 3 & Greco Island & Mudflat & $37.51859^{\circ} \mathrm{N}, 122.18336^{\circ} \mathrm{W}$ & EU797465 \\
\hline Foliaceous & 3 & Marker 3 & Mudflat & $37.53518^{\circ} \mathrm{N}, 122.19519^{\circ} \mathrm{W}$ & EU797460 \\
\hline Encrusting & 4 & Coyote Point & Intertidal rocks & $37.59111^{\circ} \mathrm{N}, 122.31415^{\circ} \mathrm{W}$ & EU797461 \\
\hline Bulbous & 4 & Redwood Creek & Mudflat & $37.50564^{\circ} \mathrm{N}, 122.22692^{\circ} \mathrm{W}$ & EU797467 \\
\hline Encrusting & 4 & $\begin{array}{l}\text { Manly Harbor, } \\
\text { Sydney, Australia }\end{array}$ & Pier piling & $33.80054^{\circ} \mathrm{S}, 151.28433^{\circ} \mathrm{W}$ & EU797458 \\
\hline
\end{tabular}




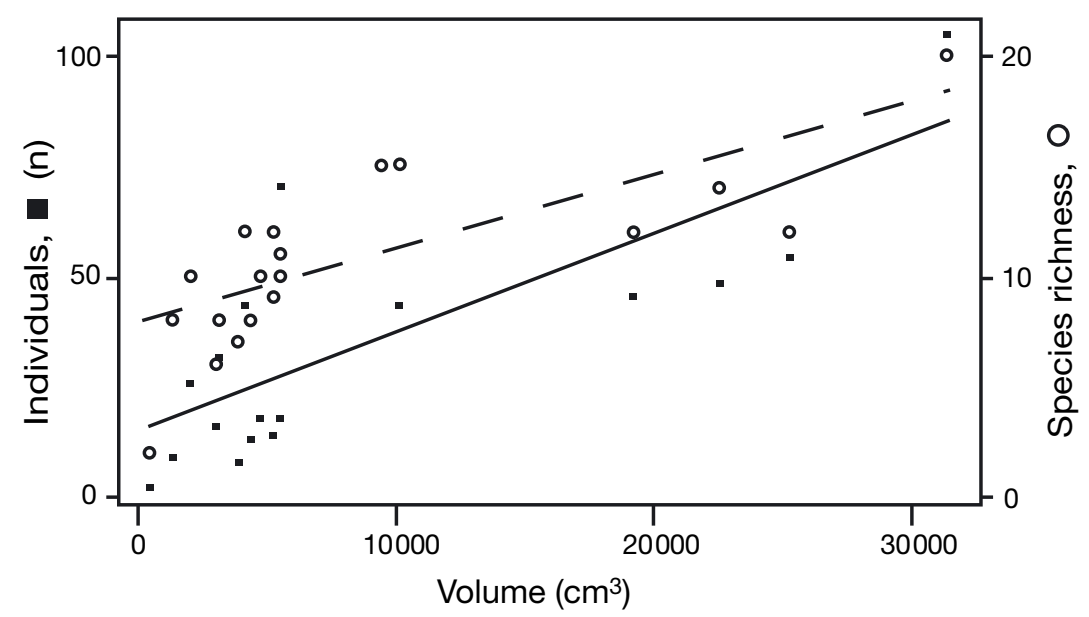

Fig. 5. Numbers of associated species (species richness) and individual organisms relative to the volume of the bryoliths

were soft-substrate dwellers. Three species were free- living.

We were able to determine the invasion status for 34 of the 50 species or morphospecies associated with the bryoliths. Of the 34, 25 (74\%) were non-natives and 9 (26\%) were natives. These percentages are roughly comparable to those from hard substrates in the marina surveys made by Cohen et al. (2005). When the Cohen et al. (2005) surveys from the 2 marinas (Coyote Point and Pete's Harbor) were combined, non-natives comprised $80 \%$ of the organisms on floating maritime structures and intertidal benthos. The percentage of non-native mud-dwelling organisms appears to be slightly higher, at $\sim 83 \%$ of the marina organisms in the benthic

haplotypes (Table 2, Fig. 4). Haplotypes differed by a maximum of $1.03 \%$ pairwise nucleotide divergence. This level of divergence is consistent with the level of intraspecific divergence that is customarily observed at a native locale in cheilostome bryozoans (Mackie 2003). Secondly, dense, foliaceous and encrusting forms were distributed among nodes of the phylogenetic network, indicating that these colony morphologies occur within a genetically connected population. The single encrusting colony from Manly, Sydney, where introduction of Schizoporella errata occurred in the 1940s (Allen 1953), was a shared haplotype with San Francisco specimens (Haplotype 4), suggesting a common native source.

\section{Associated species}

Forty-five species or morphospecies were found living in, on or among the bryoliths examined in the laboratory; an additional 5 were observed in the field (Table 3). Nearly all of these species were also found in the surveys of nearby marinas (Cohen et al. 2005); all have been previously reported from San Francisco Bay.

The numbers of individuals and species were positively correlated with the volume of the bryolith $\mathrm{r}^{2}=$ $0.543, \mathrm{p}<0.0005$ and $\mathrm{R}^{2}=0.359, \mathrm{p}=0.007$, respectively) (Fig. 5). The MDS plots (not shown) did not show any pattern of clustering by site or bryolith morphology.

Substrate associations were determined for 39 of 50 species. Fourteen species were able to use either soft or hard substrate and were mostly burrowing organisms, 12 were strictly hard-substrate species, while 10 grabs. Nearly all of the species found in the bryoliths were also found in the studies of the 2 South Bay marinas; there were no notable exceptions.

The polychaete worm Marphysa sp. C was the most abundant organism associated with the bryoliths, accounting for $27 \%$ (173 ind.) of the 649 ind. present in the samples. The genus Marphysa is in need of revision; thus, it is hard to say whether this species, which has been found by L.M.H. in Tomales Bay as well as previously in San Francisco Bay, is a non-native or a native that has been confused with the invasive polychaete Marphysa sanguinea (Montagu 1813) in the past.

Two non-native species, the anemone Diadumene leucolena (Verrill 1866) and the oyster drill Urosalpinx cinerea (Say 1822) were the next most abundant species, together accounting for $30 \%$ of total individuals found.

\section{DISCUSSION}

\section{Morphological plasticity: an environmental response?}

Schizoporella errata in its encrusting form has been reported from San Francisco Bay since 1979 (J. Inase unpubl.), but the bryolith forms, as far as we can determine, have until now gone unnoticed by scientists. From discussions with former boat captains of the 'Brownlee' and its predecessor (they recall pulling up 'orange rocks' in dredges), it appears that bryoliths have existed in the bay for at least $30 \mathrm{yr}$. Rider \& Enrico (1979), without providing information on how they arrived at this estimate, suggest a growth rate of 8 to 10 
Table 3. Taxa associated with bryoliths. * Species observed on bryoliths during the course of this research, but not found in our 19 samples

\begin{tabular}{|c|c|c|c|}
\hline & Species & Status & Substrate \\
\hline \multirow[t]{2}{*}{ Chlorophyta } & Ulva sp.* & Cryptogenic & Hard \\
\hline & Unidentified green filamentous algae & Unknown & Hard \\
\hline \multirow[t]{2}{*}{ Porifera } & Halichondria bowerbanki & Introduced & Hard \\
\hline & Clathria prolifera* ${ }^{*}$ & Introduced & Hard \\
\hline \multicolumn{4}{|l|}{ Cnidaria } \\
\hline Hydrozoa & Pinauay crocea & Introduced & Hard \\
\hline Anthozoa & Diadumene leucolena & Introduced & Hard \\
\hline Nematoda & Unidentified nematodes & Unknown & Unknown \\
\hline \multicolumn{4}{|l|}{ Annelida } \\
\hline Oligochaeta & Unidentified oligochaetes & Unknown & Unknown \\
\hline \multirow[t]{20}{*}{ Polychaeta } & Capitella capitata complex & Unknown & Soft \\
\hline & Heteromastus filiformis & Introduced & Soft \\
\hline & Cirriformia spirabrancha & Native & Soft \\
\hline & Marphysa sp. C & Unknown & Unknown \\
\hline & Glycinde sp. & Native & Soft \\
\hline & Neanthes succinea & Introduced & Multiple \\
\hline & Nereis latescens & Native & Algal holdfasts \\
\hline & Harmothoe imbricata & Native & Multiple \\
\hline & Dipolydora sp. & Unknown & Unknown \\
\hline & Polydora cornuta & Introduced & Soft \\
\hline & Sphaerosyllis sp. 8 Harris & Unknown & Unknown \\
\hline & Sphaerosyllis sp. SF1 Harris & Unknown & Unknown \\
\hline & Syllis gracilis complex & Native & Algal holdfasts \\
\hline & Typosyllis armillaris & Cryptogenic & Unknown \\
\hline & Typosyllis elongata & Native & Algal holdfasts \\
\hline & Typosyllis nipponica & Introduced & Multiple \\
\hline & Cirriformia sp. & Unknown & Unknown \\
\hline & Neoamphitrite sp. A Harris & Introduced & Soft \\
\hline & Polycirrus sp. & Unknown & Unknown \\
\hline & Unidentified species 1 & Unknown & Unknown \\
\hline \multicolumn{4}{|c|}{ Arthropoda: Crustacea } \\
\hline Cirripedia & Amphibalanus improvisus & Introduced & Hard \\
\hline \multicolumn{4}{|l|}{ Malacostraca } \\
\hline \multirow[t]{2}{*}{ Isopoda } & Gnorimosphaeroma oregonense & Native & Hard \\
\hline & Sphaeroma quoianum & Introduced & Multiple \\
\hline \multirow[t]{4}{*}{ Amphipoda } & Ampelisca abdita & Introduced & Multiple \\
\hline & Paranthura japonica & Native & Multiple, algal holdfasts \\
\hline & Monocorophium acherusicum & Introduced & Fouling/soft \\
\hline & Monocorophium insidiosum & Introduced & Fouling \\
\hline \multirow[t]{2}{*}{ Decapoda } & Palaemon macrodactylus* & Introduced & Free-living \\
\hline & Pyromaia tuberculata* & Native & Free-living \\
\hline \multicolumn{4}{|l|}{ Mollusca } \\
\hline \multirow[t]{5}{*}{ Bivalvia } & Corbula amurensis & Introduced & Soft \\
\hline & Musculista senhousia & Introduced & Multiple \\
\hline & Mytilus sp. & Unknown & Unknown \\
\hline & Gemma gemma & Introduced & Soft \\
\hline & Venerupis philippinarum & Introduced & Soft \\
\hline \multirow[t]{3}{*}{ Gastropoda } & Urosalpinx cinerea & Introduced & Hard \\
\hline & Philine sp. & Introduced & Soft \\
\hline & Unidentified nudibranch & Unknown & Unknown \\
\hline \multirow[t]{3}{*}{ Bryozoa } & Bugula stolonifera & Introduced & Hard \\
\hline & Anguinella palmata & Introduced & Hard \\
\hline & Parasmittina sp. & Unknown & Hard \\
\hline \multicolumn{4}{|l|}{ Chordata } \\
\hline Urochordata & Molgula manhattensis & Introduced & Hard \\
\hline Pisces & Acanthogobius flavomanus* & Introduced & Free-living \\
\hline
\end{tabular}


zooid layers $\mathrm{yr}^{-1}$ for Membranipora flabellata Canu (1904) bryoliths in the Gulf of Mexico; it seems to us that growth rate should vary greatly with conditions. Using Rider \& Enrico's estimate, some of the larger bryoliths we collected would be $>80 \mathrm{yr}$ old.

The unattached spherical bryolith form has not been reported in this species elsewhere, although Schizoporella errata is known to form reef-like shapes in other locations (Cocito et al. 2000). In low-energy environments in the Mediterranean Sea, S. errata transitions from multiserial structures into erect branched buildups. This structure is often the result of overgrowth of soft-bodied organisms such as hydroids and sponges; subsequent death and decay of the overgrown organisms leave empty tube-like structures. This may be how the reef-like and foliaceous shapes reported here form. It is not clear what determines whether a colony in San Francisco Bay will take on an encrusting or bryolith form or why a bryolith will take on a dense bulbous shape or a delicate foliaceous form.

Workers elsewhere have postulated that nodular growth forms in bryozoans may be mediated by a reaction to overgrowth by microbial mats (Palinska et al. 1999), heavy siltation (Jackson 1979), limited substrate and high variability in food supply (Scholz \& Hillmer 1995), or an interaction between hydrodynamics and other benthic organisms (Cocito et al. 2000). That many of the bulbous bryoliths in South Bay approximate a sphere suggests that they are turned with enough frequency to allow for relatively even growth in all directions. Elsewhere, well-rounded bryoliths have been thought to be indicators of moderately highenergy environments, although bioturbation has also been suggested as a possible factor (Rider \& Enrico 1979, Cuffey \& Johnson 1997). Tidal currents that run through the South Bay can attain speeds of 3.5 knots on an outgoing or incoming tide and wind waves of up to $2 \mathrm{~m}$ can occur in the deep central channel of the South Bay, although wave heights decrease over the shallow mudflats where the bryoliths were found. Alternatively, bryoliths could be turned by animals such as crabs, rays and other fishes foraging or burrowing on the mudflats.

Whatever its cause, this unique morphology may aid this species in spreading throughout the bay in 2 ways: (1) the spheroidal colony shape may allow this organism to disperse with wind and wave currents, and (2) fragments which escape burial should be able to form new colonies.

It has long been recognized that at the interspecific level, strong correlations exist between colony morphology and habitat characteristics such as sediment carbonate content and environmental energy (Stach 1936, Cheetham \& Thomsen 1981, Nelson et al. 1988, Hageman et al. 1998, Amini et al. 2004), providing a useful tool for interpreting present and past environments. There has been less research on intraspecific phenotypic variation in bryozoans. The introduced Schizoporella errata population in San Francisco provides an excellent opportunity to study phenotypic potential in a bryozoan species, and specifically how variable colony morphology affects the local and wider colonization dynamics.

\section{Community ecology and impacts}

As predicted, a mix of soft-bottom and hard-substrate organisms were found in the bryoliths, indicating that this invasive species provides a unique substrate not equivalent to rocks and other typical hard substrate in the bay. Hard substrate is rare in the South Bay, and the bryoliths facilitate the colonization of a number of organisms that otherwise would not be able to exist on the soft mud. Although organisms associated with the bryoliths were overwhelmingly nonnative, the bryoliths do not appear to differentially promote non-natives. Previous studies in the Bay have found non-native species richness that were roughly equivalent on hard and soft substrates (e.g. Cohen et al. 2005), so this outcome is not surprising.

However, certain invasive species that are limited by hard substrate are now able to live on the mudflats. The bryoliths may serve as stepping stones for hardsubstrate dependent sessile organisms between the 'islands' of hard substrate such as rip-rap, bridge abutments and seawalls in the South Bay.

Two species that are the major foci of restoration efforts within San Francisco Bay are the native oyster Ostrea lurida Carpenter (1864) and the eelgrass Zostera marina Linnaeus 1758; these organisms were once more abundant within the Bay, including the areas that are now inhabited by the bryoliths (Bonnot 1935). The presence of bryoliths could hinder restoration efforts in the South Bay by overgrowing these species and, at least over the areas of dense bryolith coverage, by decreasing the area suitable for eelgrass to take root.

Two organisms whose presence is facilitated by the presence of bryoliths on the mudflat are also of potential concern for oyster restoration. The Atlantic anenome Diadumene leucolena has been demonstrated to be a voracious predator of Atlantic oyster larvae in laboratory trials (Steinberg \& Kennedy 1979), and thus may affect the set of native oysters in locations where it is highly abundant. The bryoliths also appear to provide excellent habitat for the Atlantic oyster drill Urosalpinx cinerea, which is generally restricted to hard substrate where its prey items are found. We found large adults, small juveniles and egg 
cases of the drill in the bryoliths, in addition to numerous bivalve shells with drill holes in them inside crevices in the bryoliths. The oyster drill is a generalist predator that has been demonstrated to consume and limit native oysters in other locations (D. L. Kimbro, UC Davis, pers. comm.).

What limits the distribution of the bryolith form is also unknown at this time. Shell substrate is available throughout much of the Bay, but is devoid of growth in many locations north of the San Mateo bridge (J.G. \& C.J.Z. pers. obs.). Conditions similar to that of the South Bay (shallow mudflats in areas of similar salinity and wave and current regimes) are found elsewhere in the bay and could presumably support bryoliths.

Logistical considerations did not allow us the time to develop standardized methods that could be replicated with enough frequency for density measurement. In initial tows, we likely pulled the dredge past the point at which it was full, making density calculation based on area covered unfeasible. Several initial tows brought up only well-rounded bryoliths, but later tows brought up a mix of shells and bryoliths in various stages of development, making it challenging to decide what should be counted as a bryolith vs. a bryozoan-encrusted shell. However, our observations suggest that the bryoliths are quite dense in some locations, including over one rather large area. Considering the potential impact that the bryoliths could have on the bay ecosystem, mapping the density of this growth form is an important next step.

Acknowledgements. We thank S. Attoe and E. D. Grosholz for field assistance, C. W. Brown for sponge and amphipod identifications, J. Winston for initial identification of the bryozoan and discussions about bryoliths, D. Steller and M. Foster for discussions about rhodoliths, the Marine Science Institute in Redwood City (CA), and G. M. Ruiz and E. D. Grosholz for laboratory and logistical support. J. T. Carlton and an anonymous reviewer provided comments that greatly improved this paper.

\section{LITERATURE CITED}

Allen FE (1953) Distribution of marine invertebrates by ships. Aust J Mar Freshw Res 4:307-316

Amini ZZ, Adabia MH, Burretta CF, Quiltya PG (2004) Bryozoan distribution and growth form associations as a tool in environmental interpretation, Tasmania, Australia. Sediment Geol 167:1-15

Banta WC (1972) The body wall of the cheilostome Bryozoa, V. Frontal budding in Schizoporella unicornis floridana. Mar Biol 14:63-71

Bonnot P (1935) The California oyster industry. Cal Fish Game 21:65-80

Bosence DWJ (1983) The occurrence and ecology of recent rhodoliths - a review. In: Peryt TM (ed) Coated grains. Springer Verlag, Heidelberg, p 225-242

Bradstock M, Gordon DP (1983) Coral-like bryozoan growths in Tasman Bay, and their protection to conserve commer- cial fish stocks. N Z J Mar Freshw Res 17:159-163

Bruno JF, Fridley JD, Bromberg KD, Bertness MD (2005) Insights into biotic interactions from studies of species invasions. In: Sax DF, Stachowicz JJ, Gaines SD (eds) Species invasions: insights into ecology, evolution and biogeography. Sinauer Associates, Sunderland, MA, p 13-40

Carlton JT (1979) History, biogeography, and ecology of the introduced marine and estuarine invertebrates of the Pacific Coast of North America. PhD dissertation, University of California, Davis

Carlton JT (1996) Biological invasions and cryptogenic species. Ecology 77:1653-1655

Cheetham AX, Thomsen E (1981) Functional morphology of arborescent animals: strength and design of cheilostome bryozoan skeletons. Paleobiology 7:355-383

Clement M, Posada D, Crandall KA (2000) TCS: a computer program to estimate gene genealogies. Mol Ecol 9: $1657-1660$

Cocito S, Ferdeghini F, Morri C, Bianchi CN (2000) Patterns of bioconstruction in the cheilostome bryozoan Schizoporella errata: the influence of hydrodynamics and associated biota. Mar Ecol Prog Ser 192:153-161

Cohen AN, Carlton JT (1995) Nonindigenous aquatic species in a United States estuary: a case study of the biological invasions of the San Francisco Bay and delta. US Fish and Wildlife Service, Washington, DC

Cohen AN, Calder DR, Carlton JT, Chapman JW and others (2005) Rapid assessment shore survey for exotic species in San Francisco Bay-May 2004. Final report. California State Coastal Conservancy, Association of Bay Area Governments/San Francisco Bay-Delta Science Consortium, National Geographic Society and Rose Foundation, Oakland, CA

Crooks JA, Khim HS (1999) Architectural vs. biological effects of a habitat-altering, exotic mussel, Musculista senhousia. J Exp Mar Biol Ecol 240:53-75

Cuffey RJ, Johnson ME (1997) Bryozoan nodules built around andesite clasts from the upper Pliocene of Baja California: paleoecological implications and closure of the Panama Isthmus. Geol Soc Am Spec Pap 318:111-117

Cuffey RJ, Sorrentino AV (1985) Globular Ceriopora species (Cyclostomida, Bryozoa) from the Virginia-Carolinas Pliocene, and the status of Atelesopora. In: Nielsen C, Larwood GP (eds) Bryozoa: Ordovician to recent. Olsen \& Olsen, Fredensborg, p 79-86

Ferdeghini F, Cocito S, Morri C, Bianchi CN (2000) Living bryozoan buildups: Schizoporella errata (Waters, 1848) (Cheilostomata, Ascophorina) in the Northwestern Mediterranean (preliminary observations). In: Herrera CA, Jackson JBC (eds) Proc 11th Int Bryozoology Assoc Conf, Jan 26-31, 1998, Panama City, p 238-244

Foster MS (2001) Rhodoliths: between rocks and soft places. J Phycol 37:659-667

Glynn PW (1974) Rolling stones among the Scleractinia: mobile coralliths in the Gulf of Panama. Proc 2nd Annu Int Coral Reef Symp 2:183-198

Hageman SJ, Bock PE, Bone Y, McGowran B (1998) Bryozoan growth habits: classification and analysis. J Paleontol 72 : 418-436

Heiman KW, Vidargas N, Micheli F (2008) Non-native habitat as home for non-native species: comparison of communities associated with invasive tubeworm and native oyster reefs. Aquat Biol 2:47-56

Hillmer G, Scholz J, Dullo WC (1996) Two types of bryozoan nodules from the Gulf of Aqaba, Red Sea. In: Gordon DP, Smith AT, Grant-Mackie JA (eds) Bryozoans in space and time. National Institute of Water and Atmospheric 
Research, Wellington, p 125-131

Jackson JBC (1979) Morphological strategies of sessile animals. In: Larwood GP, Rosen BR (eds) Biology and systematics of colonial organisms. Academic Press, London, p 499-555

James DW, Foster MS, O'Sullivan J (2006) Bryoliths (bryozoa) in the Gulf of California. Pac Sci 60:117-124

Kidwell SM, Gyllenhaal ED (1998) Symbiosis, competition, and physical disturbance in the growth histories of Pliocene cheilostome bryoliths. Lethaia 31:221-239

Lorenzi AH, Cain DJ, Parchaso F, Thompson JK and others (2007) Near-field receiving water monitoring of trace metals and a benthic community near the Palo Alto Regional Water Quality Control Plant in South San Francisco Bay, California: 2006. Open File Report 2007-1199, US Geological Survey, Palo Alto, CA

Mackie JA (2003) A molecular analysis of bryozoan dispersal. PhD dissertation, University of Melbourne

Mackie JA, Keough MJ, Christidis L (2006) Invasion patterns inferred from cytochrome oxidase I sequences in three bryozoans, Bugula neritina, Watersipora subtorquata, and Watersipora arcuata. Mar Biol 149:285-295

> Morgado EH, Tanaka MO (2001) The macrofauna associated with the bryozoan Schizoporella errata (Walters) in southeastern Brazil. Sci Mar 65:173-181

Nelson CS, Keane SL, Leask WL, Gordon DP (1988) Application of bryozoan zoarial growth-form studies in facies of non-tropical carbonate deposits in New Zealand. Sediment Geol 60:301-322

Osburn RC (1912) The Bryozoa of the Woods Hole region. Bull US Bur Fish 30:203-266

Posey MH (1988) Community changes associated with the spread of an introduced seagrass, Zostera japonica. Ecology 69:974-983

Palinska KA, Scholz J, Sterflinger K, Gerdes G, Bone Y (1999)

Editorial responsibility: Charles Birkeland,

Honolulu, Hawaii, USA
Microbial mats associated with bryozoans (Coorong Lagoon, South Australia). Facies 41:1-14

Ricciardi A, Whoriskey FG, Rasmussen JB (1997) The role of the zebra mussel (Dreissena polymorpha) in structuring macroinvertebrate communities on hard substrata. Can J Fish Aquat Sci 54:2596-2608

Rider J, Enrico R (1979) Structural and functional adaptations of mobile Anascan ectoproct colonies (ectoproctaliths). In: Larwood GP, Abbott MB (eds) Advances in bryozoology. Academic Press, New York, p 297-320

> Rodriguez LF (2006) Can invasive species facilitate native species? Evidence of how, when and why these impacts occur. Biol Invas 8:927-939

> Scholz J, Hillmer G (1995) Reef-bryozoans and bryozoanmicroreefs: control factor evidence from the Philippines and other regions. Facies 32:109-144

Stach LW (1936) Correlation of zoarial form with habitat. J Geol 44:60-65

Steinberg PD, Kennedy VS (1979) Predation upon Crassostrea virginica (Gmelin) larvae by two invertebrate species common to Chesapeake Bay oyster bars. Veliger 22: 78-84

Tompsett S, Porter JS, Taylor PD (2009) Taxonomy of the fouling cheilostome bryozoans Schizoporella unicornis (Johnston) and Schizoporella errata (Waters). J Nat Hist 43: $2227-2243$

> Wasson K, Zabin CJ, Bedinger L, Diaz MC, Pearse JS (2001) Biological invasions of estuaries without international shipping: the importance of intraregional transport. Biol Conserv 102:143-153

> Wasson K, Fenn K, Pearse JS (2005) Habitat differences in marine invasions of central California. Biol Invasions 7: 935-948

Winston JE (2004) Bryozoans from Belize. Atoll Res Bull 523: $1-23$

Submitted: September 10, 2009; Accepted: May 14, 2010

Proofs received from author(s): July 24, 2010 